\title{
Lyophilized Fruit Juice of Citrus sinensis Triggers Mitochondria-mediated Apoptosis via Down- regulation of PI3K/AKT in MCF-7 Cell Line
}

\author{
Jayasindu Mathiyazhagan'1, John Arul Daniel', George Priya C. Doss', Rama Jayaraj², Kodiveri \\ Muthukaliannan Gothandam ${ }^{1, *}$
}

${ }^{1}$ School of Bio Sciences and Technology, Vellore Institute of Technology (VIT), Vellore-14, Tamil Nadu, INDIA.

${ }^{2}$ Theme Lead, Flinders NT, Flinders University, Northern Territory 0909, AUSTRALIA.

\begin{abstract}
Background: Breast cancer is prevalent cancer among women and a major cause of death worldwide due to various genetic and environmental factors. Citrus sinensis is widely taken fruit juice in most countries that are believed to reduce breast cancer risk. However, the mechanism through which it acts remains unclear. Our objective was to explore the mechanism through which Citrus sinensis acts as a cytotoxic agent. Materials and Methods: FT-IR and GC-MS analyses of lyophilzed orange juice (LOJ) were performed to find phytocompounds that were subjected to in silico docking analysis against phosphatidylinositol-3-kinase (PI3K)/protein kinase $B(A K T) /$ mammalian target of rapamycin (mTOR) pathway. The proteins that showed the low free energy of binding was taken for gene expression analysis. RT-PCR analysis was carried out to observe $\mathrm{PI3K} / \mathrm{AKT} / \mathrm{mTOR}$ genes inhibition in LOJ treated cells. Cytotoxicity, apoptosis, caspase 9 activity were performed against the human breast cancer cell line (MCF-7). Results: The docking analysis against PI3K/AKT/mTOR with LOJ compounds showed the best interactions. Further down-regulation of PI3K/AKT and moderate up-regulation of mTOR was confirmed using gene expression analysis. LOJ showed concentration-dependent cytotoxicity, apoptosis, decreased mitochondrial membrane stability and caspase 9 against the MCF-7 cell line. Conclusion: This study concludes that LOJ can induce apoptosis in MCF-7 cells via PI3K and AKT inhibition.
\end{abstract}

Key words: Lyophilized orange juice, Molecular docking, Apoptosis, MCF-7 cell line, $\mathrm{PIJK} / \mathrm{AKT} / \mathrm{mTOR}$.

\section{INTRODUCTION}

In women, breast cancer accounts for the majority of cancer death around the globe. ${ }^{1}$ Even though ongoing treatments have shown a better effect against breast cancer, it could not completely cure the nefarious activity of metastasis or advanced breast cancer stages. ${ }^{2}$ Apoptosis or programmed cell death is a natural phenomenon to remove impaired and redundant cells. Apoptosis is triggered by various factors, including anticancer drugs, growth factors and oxidative stress. ${ }^{3}$ There are two apoptotic pathways, namely, intrinsic or mitochondrial-induced pathway and extrinsic or receptor-induced pathway. Caspases are essential components of the apoptotic process, in which caspase 9 (intrinsic initiator) is a promising therapeutic target against proliferative diseases like cancer. ${ }^{4}$

Oxidative stress enacts a vital role in discrete human diseases, including cancer. ${ }^{5}$ Oxidative stress is enhanced by reactive oxygen species (ROS) that act via various exogenous and endogenous stimuli, resulting in cell injury. ROS includes hydrogen peroxide, superoxide anion radicals and hydroxyl radicals controlled by oxidation and antioxidant systems under normal physiological conditions. ${ }^{6}$ At the cellular level, PI3K/ $\mathrm{AKT} / \mathrm{mTOR}$ contributes to increased ROS
Submission Date: 21-08-2020; Revision Date: 06-01-2021: Accepted Date: 12-03-2021

DOI: 10.5530/ijper.55.2.94 Correspondence: Dr. KM Gothandam Professor, School of Bio Sciences and Technology, VIT University, Vellore-632 014, Tamil Nadu, INDIA Phone no: +91-9489337967 Email id: gothandam@gmail. com

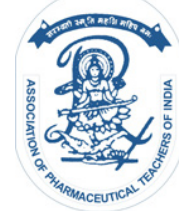

www.ijper.org 
production by directly modulating the bioenergetics of mitochondria or indirectly as a metabolic by-product. ${ }^{7}$ The down-regulation of this pathway activates caspase 9 dependent mitochondrial apoptosis. ${ }^{8}$ The PI3K/AKT/ mTOR pathway is a major signalling pathway involved in cell cycle regulation and progression. Hyperactivation of proteins in this pathway leads to inflated feedback inhibition of components in the signalling network, resulting in down-regulation of receptors and their signals, which led to the development of inhibitors for this pathway. It is necessary to develop an inhibitor of the PI3K/AKT/mTOR pathway with fewer side effects that act efficaciously in breast cancer cells.

Compared to synthetic drugs, natural products are preferable because they show low toxicity and decidedly fewer side effects.' Many phytocompounds wield chemopreventive activities against breast cancer. One of them is citrus fruits, which belong to the Rutaceae family grown throughout the world. It encompasses Citrus sinensis (sweet orange), Citrus reticulate (tangerine tree), Citrus vitis (grapefruit tree), Citrus aurantifulia (lime tree) and Citrus limonum (lemon tree). Owing to the phytonutrient contents, all citrus fruits hold similar therapeutic and dietetic properties. ${ }^{10}$ Phytonutrients are plant nutrients that advocate human health and disease prevention through their specific biological activities. Myriads of biologically active products are provided by plant secondary metabolites, including flavonoids, phenolics and terpenoids. ${ }^{11}$ Citrus fruits are a source of flavanones, flavones and polymethoxylated flavones that has myriad bioactivities. ${ }^{12,13}$ Our preliminary data showed that lyophilized orange juice (LOJ) is rich in phenolic acids and flavonoids, thus scavenging ROS. The intracellular mechanism of cancer cell death was achieved by ROS induced mitochondria-mediated apoptosis via down-regulation of PI3K and AKT.

\section{MATERIALS AND METHODS}

\section{Collection and preparation of pure Citrus sinensis juice powder}

Fresh sweet oranges were purchased from a local market in Vellore district, Tamil Nadu, India. The skin was removed from each of the endocarp segments present in the orange. Pure juice was obtained from the orange by crushing the fruit using a mortar pestle. The juice was filtered, and the filtrate was then lyophilized to acquire a water-free sample. The lyophilized sample was then dissolved in methanol for further analysis.

\section{Quantitative determination of phytochemicals}

The total phenolic content (TPC) and the total flavonoid content (TFC) present in the LOJ were quantified using the Folin-Ciocalteu and aluminium chloride colorimetric methods. ${ }^{14,15}$ The results were indicated $\mathrm{mg} / \mathrm{g}$ GAE (gallic acid equivalent) weight for TPC and $\mathrm{mg} / \mathrm{g}$ QE (quercetin equivalent) for TFC.

\section{FT-IR and GC-MS analysis}

The functional groups of the LOJ were established using Fourier-transform infrared spectroscopy analysis. $10 \mathrm{mg}$ of the dried powder was added to $100 \mathrm{mg}$ of potassium bromide pellet to produce pellucid sample discs. The sample was loaded in FT-IR spectroscopy in the range of 4000 to $400 \mathrm{~cm}^{-1}$.

Gas chromatography-mass spectrometry analysis of LOJ was done to identify the phytoconstituents. The sample was loaded in Elite - 5MS capillary column with $30 \mathrm{~m}$ X $0.25 \mathrm{~mm}$ ID X $0.25 \mu \mathrm{m}$ df with helium as carrier gas at $1 \mathrm{ml} / \mathrm{min}$ flow rate. Mass spectral patterns were matched with the NIST library for the determination of structures.

\section{Antioxidant activity}

The free radical scavenging activity of LOJ was achieved to find its antioxidant activity. ${ }^{16} 1 \mathrm{~mL}$ of 0.3mM 2,2-diphenyl-1-picrylhydrazyl (DPPH) solution in methanol was combined to $2.5 \mathrm{~mL}$ of different concentrations of the sample. Then the samples were stored in the dark for $30 \mathrm{~min}$. The optical density of these samples was taken at $518 \mathrm{~nm}$.

\section{In silico docking analysis}

Three-dimensional structures of compounds identified by GC-MS analysis were fetched from PubChem. The ligands that passed Lipinski's rule of five were taken for docking studies. The three-dimensional structures of PI3K $\alpha$ (4JPS), AKT (3MV5) and mTOR (4JSX) proteins were retrieved from the Protein Data Bank and were used as the target for the phytocompounds. ${ }^{17}$

Autodock 4 was used for the docking simulation to run and analyse. Polar hydrogen and Kollman charges were included. The Lamarckian genetic algorithm was chosen to search the global optimised and the best conformation. The default parameters were used for docking studies. After ten runs, the best confirmation of the ligand was selected based on the lowest binding energy.

\section{Cell cytotoxicity assay}

Cell cytotoxicity was estimated in the MCF-7 cell line using MTT (3-(4,5-dimethylthiazol-2-yl)2,5diphenyltetrazolium bromide). MCF-7 cells were seeded onto a 96-well tissue culture plate and kept in 5\% $\mathrm{CO}_{2}$ at $37^{\circ} \mathrm{C}$ humidified incubator. After cell attachment, cells were treated with different concentrations of LOJ (10, 
$50,75,100,150$ and $200 \mu \mathrm{g} / \mathrm{mL}$ ) for $24 \mathrm{~h}$. Following the treatment period, $20 \mu \mathrm{l}$ of MTT was added to the wells at a $2.5 \mathrm{mg} / \mathrm{mL}$ concentration. After $4 \mathrm{hrs}$ MTT was removed from the wells, and metabolically active cells were measured using a microtiter plate reader at 570 $\mathrm{nm}$ wavelength. An inverted phase-contrast microscope was used to observe cell morphology changes in the MCF-7 cell line after treatment with LOJ. The cells were captured using the phase-contrast microscope for morphological changes (100X magnification).

\section{AO/EB staining}

LOJ induced apoptosis was studied by acridine orange (AO)/ethidium bromide (EB) dual staining. AO emits green fluorescence by taking up the nuclear DNA of live and damaged cells. EB emits red fluorescence by taking up nuclear DNA from damaged cells, which have entered the late apoptotic stage. ${ }^{18}$ An equal amount of $\mathrm{AO}$ and $\mathrm{EB}(100 \mu \mathrm{g} / \mathrm{mL})$ was added to the plates containing untreated control cells, and LOJ treated cells $\left(\mathrm{IC}_{50}=185.5 \mu \mathrm{g} / \mathrm{mL}\right)$. Apoptosis was observed under a fluorescent microscope (Lawrence and Mayo (India) Pvt. Ltd).

\section{Mitochondrial membrane staining}

Rhodamine 123 is a cationic green-fluorescent dye that aggregates and accumulates in normal cells of the mitochondrial membrane. This dye binds only to the metabolically active mitochondria. The untreated control cells and LOJ treated cells were incubated with $5 \mu \mathrm{g} / \mathrm{ml}$ of rhodamine 123 dye for $30 \mathrm{~min}$. The stained cells were viewed under a fluorescent microscope at 505 $\mathrm{nm}$ excitation with $534 \mathrm{~nm}$ emission (Lawrence and Mayo (India) Pvt. Ltd) for mitochondrial membrane potential changes.

\section{DCFH-DA method and caspase 9 activity}

The 2',7'-dichlorofluorescein diacetate (DCFH-DA) method was used to measure ROS levels using flow cytometry. The cells were treated with the $\mathrm{IC}_{50}$ concentration of LOJ for $24 \mathrm{~h}$ and trypsinized. The cells were washed and incubated with $20 \mu \mathrm{M} \mathrm{DCFH-DA}$ for $30 \mathrm{~min}$ in darkness. ROS levels were then estimated using flow cytometry. The results were analyzed using cytexpert software (CytoFLEX, Beckman Coulter, USA). Caspase 9 activity was measured at an absorbance of $405 \mathrm{~nm}$ using a caspase 9 colorimetric assay kit (Biovision, CA, USA).

\section{Real-time polymerase chain reaction (RT-PCR)}

Total RNA was obtained from control and LOJ treated $(185.5 \mu \mathrm{g} / \mathrm{mL})$ MCF-7 cells using TRIzol reagent. The cDNA was synthesised using RNA and reverse transcribed using cDNA reverse transcription kit. The qRT-PCR was carried out with SYBR ${ }^{\circledR}$ Premix Ex Taq $^{\text {TM }}$ on the CFX96 ${ }^{\mathrm{TM}}$ RealTime System (BIO-RAD, California, USA). The primer sequences used were: $\beta$-actin, forward primer 5'-GTCATTCCAAATATGAGATGCGT-3' and reverse primer 5'-GCTATCACСТCСССТGTGTG-3'; PIK3CA, forward primer 5'-AT'TGTCGTGCATGTGG GATG-3' and reverse primer 5'-AATCTGGTCGC CTCATTTGC-3'; AKT, forward primer 5'- GGACA AGGACGGGCACATTA-3' and reverse primer 5'-CG ACCGCACATCATCTCGTA-3'; mTOR, forward primer 5'- TGCCTTTGAGCAGAAAAGGT-3' and reverse primer 5'- CTGGTT'TCACCAAACCGTCT-3'. The comparative threshold cycle $\left(2^{-\Delta \Delta t}\right)$ calculation was utilised to calculate gene expression.

\section{Statistical analysis}

The data of all the assays with three replicates are subjected to statistical analysis and are given as mean \pm standard deviation (SD) using GraphPad Prism 7 software. The comparison between groups were analysed with a one-way analysis of variance (ANOVA) followed by the Tukey test. The significance was considered when $p<0.05$.

\section{RESULTS}

\section{Quantitative and qualitative determination of phytochemicals}

The TPC in LOJ was calculated from the calibration curve $\left(R^{2}=0.99\right)$ that was estimated to be $1.233 \pm 0.01$ mg GAE/g dry weight and total flavonoid $\left(R^{2}=0.99\right)$ was estimated to be $0.995 \pm 0.04 \mathrm{mg} Q \mathrm{QE} / \mathrm{g}$ dry weight. The antioxidant activity of LOJ using DPPH assay is shown in Figure 1. The scavenging activity of LOJ was $53 \%$ at $300 \mu \mathrm{g} / \mathrm{mL}$ concentration against ascorbic acid

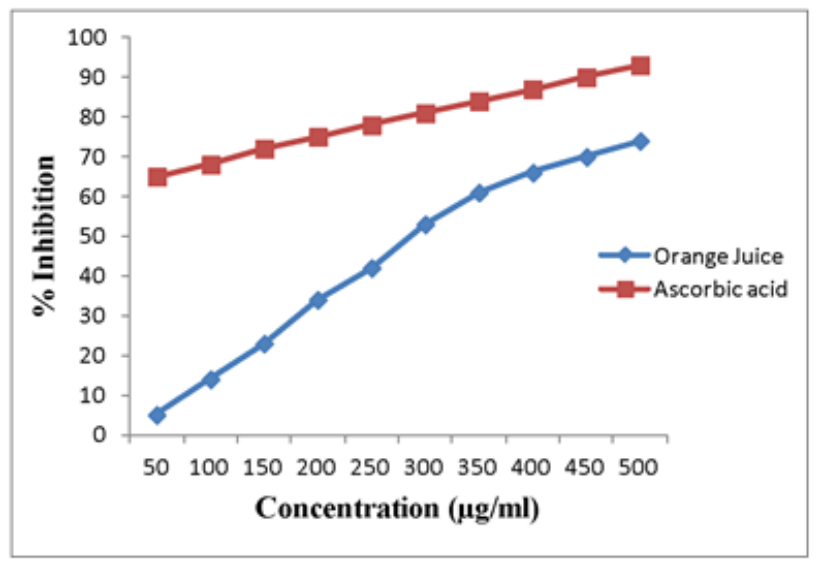

Figure 1: DPPH radical scavenging assay; LOJ against standard compound ascorbic acid. 
( $81 \%$ at $300 \mu \mathrm{g} / \mathrm{mL}$ ). Numerous secondary metabolites like phenolics and flavonoids act as antioxidants that perform scavenging activity. ${ }^{19}$ There was a significant positive correlation between total phenolics and antioxidant $\left(R^{2}=0.988\right)$, as well as with total flavonoids and antioxidants $\left(R^{2}=0.980\right)$.

The FT-IR peak values are shown in Table 1 . The spectrum was used to find the functional groups in the LOJ. The powder showed the presence of phenols, acetates and formates. A total of 41 compounds from LOJ were identified by GC-MS, which belongs to families such as esters, ethers, aldehydes, alcohols and terpenes.

\section{In silico interaction analysis}

Bioavailability is one of the fundamental pharmacokinetic properties of drugs. Bioavailability is the rate of absorption of a drug available at the site of physiological activity after administration. The ligands' bioavailability and drug likeliness were studied with the pkCSM software and Molinspiration tool (Table 2), respectively. ${ }^{20}$ The compounds passing Lipinski's rule were chosen for further analysis. These screened compounds were taken for molecular docking analysis against the $\mathrm{PI} 3 \mathrm{~K} / \mathrm{AKT} / \mathrm{mTOR}$ pathway receptors. LOJ compounds were used for docking analysis with these target proteins to find their molecular interactions. The co-crystallized ligands were docked with their specific proteins, and the interactions were noted. The lowest binding affinities and best interactions of the ligands were compared with its specific inhibitor (Table 3).

\section{In vitro analysis}

The cell cytotoxicity assay results reported that the LOJ has concentration-dependent cytotoxicity activity

\begin{tabular}{|c|c|c|}
\multicolumn{3}{|c|}{ Table 1: FT-IR analysis to identify compound present } \\
in lyophilized orange juice.
\end{tabular}

against the MCF-7 cell line after $24 \mathrm{~h}$ of treatment with LOJ compared with the control. The cell viability is mentioned in Figure 2. The morphological examination of untreated control cells was elongated in shape and grown completely. Whereas the cells treated with LOJ $\left(\mathrm{IC}_{50}-185.5 \mu \mathrm{g} / \mathrm{ml}\right.$ ) showed a reduction in cell size, spheroid shape, shrinkage and detachment of cells, indicating cell death. The observed morphological changes are given in Figure $3 \mathrm{a}$ and $3 \mathrm{~b}$.

The images of $\mathrm{AO} / \mathrm{EB}$ staining of MCF-7 cells with and without LOJ treatment are depicted in Figure $3 \mathrm{c}$ and $3 \mathrm{~d}$. The cells without treatment were green in colour, indicating the live cell population and the cells treated with LOJ had half of the cells turned completely orange

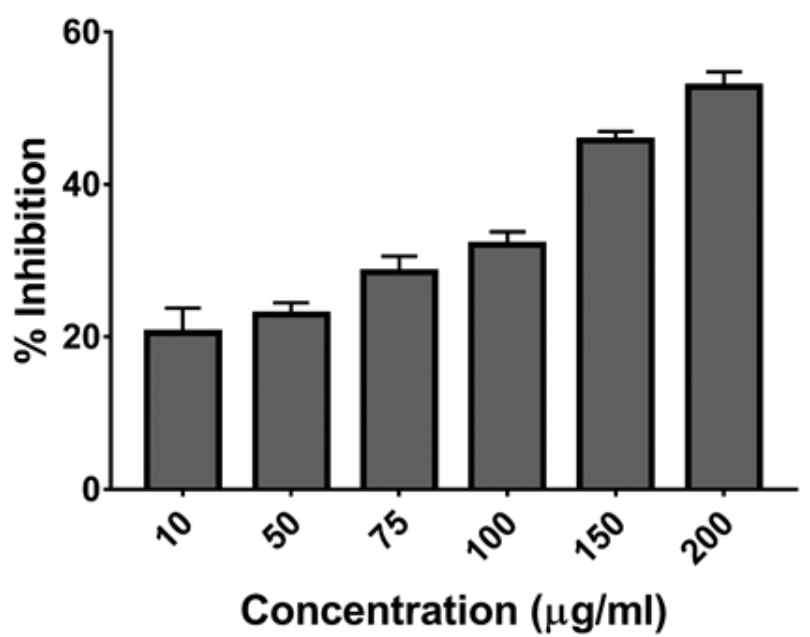

Figure 2: Effect of different concentrations of LOJ on Viability of MCF-7 cell lines. Cell cytotoxicity was observed after $24 \mathrm{hr}$ of treatment with LOJ.
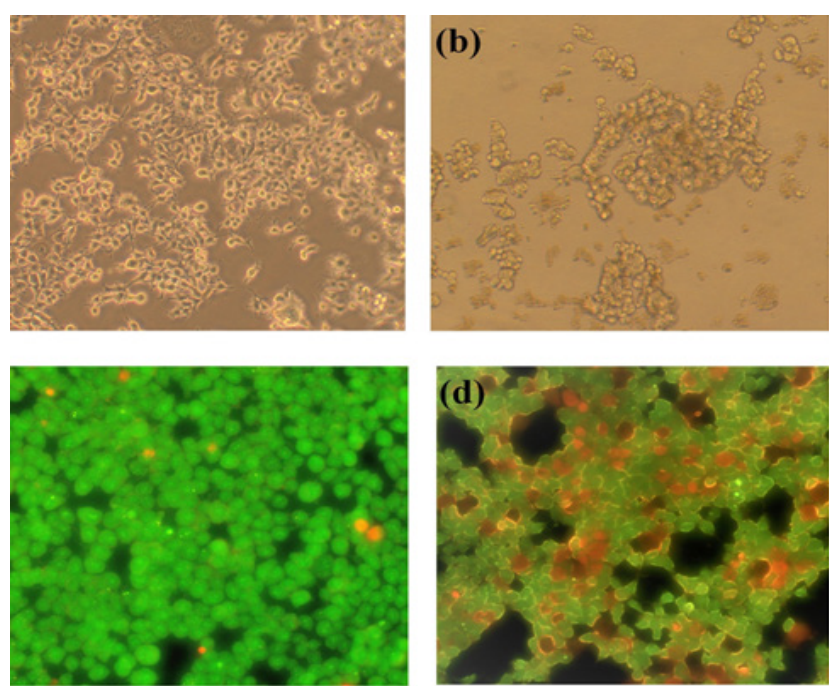

Figure 3: Morphology changes in MCF-7 cells (a) Control cells, (b) LOJ treated cells; AO/EB staining for the detection of apoptosis in fluorescence microscopy (200X magnification): (c) Control cells, (d) LOJ treated cells. 
Table 2: ADMET properties of LOJ compounds.

\begin{tabular}{|c|c|c|c|c|c|c|}
\hline S.No & Ligands & $\begin{array}{c}\text { Absorption- } \\
\text { Intestinal } \\
\text { absorption (human) } \\
\%\end{array}$ & $\begin{array}{l}\text { Distribution-BBB } \\
\text { Permeability (log } \\
\text { BB) }\end{array}$ & $\begin{array}{l}\text { Metabolism } \\
\text { (Cytochrome } \\
\text { enzymes) }\end{array}$ & $\begin{array}{l}\text { Excretion- } \\
\text { Total clearance } \\
(\log \mathrm{ml} / \mathrm{min} / \mathrm{kg})\end{array}$ & $\begin{array}{l}\text { Toxicity-AMES/ } \\
\text { Hepatotoxicity }\end{array}$ \\
\hline 1 & Triacetone triperoxide & 93.79 & 1.557 & No & 1.236 & No/No \\
\hline 2 & $\begin{array}{c}\text { 4-Tert- } \\
\text { Butylcyclohexanecarboxylic } \\
\text { Acid }\end{array}$ & 100 & 0.305 & No & 0.966 & No/No \\
\hline 3 & $\begin{array}{c}\text { Acetic Acid, } \\
\text { 2-Acetoxymethyl-1,2,3- } \\
\text { Trimethylbutyl Ester }\end{array}$ & 97.21 & 0.585 & No & 1.189 & Yes/No \\
\hline 4 & N-Aminomorpholine & 99.13 & -0.268 & No & 0.684 & No/No \\
\hline 5 & $\begin{array}{c}\text { 2-(Aminooxy)- Propanoic } \\
\text { Acid }\end{array}$ & 81.4 & -0.029 & No & 0.833 & No/No \\
\hline 6 & 2-Formylhistamine & 76.24 & -0.912 & No & 1.003 & No/No \\
\hline 7 & 3-Bromo-2-pentanol & 93.48 & 0.064 & No & 0.432 & Yes/No \\
\hline 8 & 5-Methoxy-3-Oxovalerate & 99.15 & -0.267 & No & 0.888 & Yes/No \\
\hline 9 & Trans-2-Chlorovinylacetate & 100 & -0.007 & No & 0.092 & No/No \\
\hline 10 & Sec-butyl isopropyl ether & 96.16 & 0.567 & No & 1.465 & No/No \\
\hline 11 & $\begin{array}{l}\text { Endo-2,3-O-Ethylidene-. } \\
\text { Beta.-D- Erythrofuranose }\end{array}$ & 100 & -0.249 & No & 0.86 & No/No \\
\hline 12 & 1,7-Octanediol & 76.97 & -0.123 & No & 0.571 & No/No \\
\hline 13 & $\begin{array}{l}\text { 3-Pentanone, } \\
\text { 1,5-Dimethoxy- Butane }\end{array}$ & 100 & -0.181 & No & 0.899 & No/No \\
\hline 14 & 1,2-Propanediol diformate & 100 & -0.26 & No & 0.729 & No/No \\
\hline 15 & $\begin{array}{l}\text { L-2-Amino-4-Methyl-1- } \\
\text { Pentanol }\end{array}$ & 77.64 & -0.244 & No & 0.725 & No/No \\
\hline 16 & Propionic Acid & 93.86 & -0.292 & No & 0.396 & No/No \\
\hline 17 & Acetal & 96.97 & 0.193 & No & 0.84 & Yes/No \\
\hline 18 & $\begin{array}{l}\text { 5-Methylene-2,4,7,9- } \\
\text { Tetraoxadecane }\end{array}$ & 84.88 & -0.208 & No & 0.354 & No/No \\
\hline 19 & $\begin{array}{c}\text { (3-Methyl-Oxiran-2-YI)- } \\
\text { Methanol }\end{array}$ & 97.32 & -0.238 & No & 0.529 & Yes/No \\
\hline 20 & $\begin{array}{l}\text { 4-Hydro-L-2-Amino-3- } \\
\text { Methyl-1- Pentanol }\end{array}$ & 77.64 & -0.244 & No & 0.725 & No/No \\
\hline 21 & Methyl Propyl Ether & 100 & 0.08 & No & 0.675 & No/No \\
\hline 22 & Diglycolic Acid & 65.78 & -0.378 & No & 0.867 & No/No \\
\hline 23 & $\begin{array}{l}\text { 2-(2-Aminoethyoxy)- } \\
\text { Ethanol }\end{array}$ & 84.02 & -0.301 & No & 1.124 & Yes/No \\
\hline 24 & Chloromethoxy methane & 100 & 0.05 & No & 0.399 & No/No \\
\hline
\end{tabular}


Table 3: Docking energy of LOJ ligands with PI3K/AKT/mTOR pathway targets.

\begin{tabular}{|c|c|c|c|c|c|c|c|}
\hline \multirow[b]{2}{*}{ S.No } & \multirow{2}{*}{$\begin{array}{c}\text { Targets } \\
\text { Ligands }\end{array}$} & \multicolumn{2}{|c|}{ PI3 } & \multicolumn{2}{|c|}{ AKT } & \multicolumn{2}{|c|}{ mTOR } \\
\hline & & $\begin{array}{l}\text { Binding } \\
\text { Energy } \\
\text { (kcal/mol) }\end{array}$ & $\begin{array}{l}\text { Hydrogen } \\
\text { bond }\end{array}$ & $\begin{array}{l}\text { Binding } \\
\text { Energy } \\
\text { (kcal/mol) }\end{array}$ & $\begin{array}{l}\text { Hydrogen } \\
\text { bond }\end{array}$ & $\begin{array}{l}\text { Binding } \\
\text { Energy } \\
(\mathrm{kcal} / \mathrm{mol})\end{array}$ & $\begin{array}{l}\text { Hydrogen } \\
\text { bond }\end{array}$ \\
\hline 1 & Triacetone triperoxide & -6.63 & VAL851 & -6.27 & $\begin{array}{l}\text { GLU191, } \\
\text { LYS179 }\end{array}$ & -6.66 & VAL2240 \\
\hline 2 & $\begin{array}{c}\text { 4-Tert- } \\
\text { Butylcyclohexanecarboxylic } \\
\text { Acid }\end{array}$ & -5.54 & VAL851 & -5.33 & ALA230 & -5.24 & VAL2240 \\
\hline 3 & $\begin{array}{c}\text { Acetic Acid, } \\
\text { 2-Acetoxymethyl-1,2,3- } \\
\text { Trimethylbutyl Ester }\end{array}$ & -4.81 & VAL851 & -4.07 & $\begin{array}{l}\text { LYS276, } \\
\text { LEU295, } \\
\text { GLY294 }\end{array}$ & -4.87 & VAL2240 \\
\hline 4 & N-Aminomorpholine & -4.5 & - & -4.94 & GLU234 & -4.33 & - \\
\hline 5 & $\begin{array}{c}\text { 2-(Aminooxy)- Propanoic } \\
\text { Acid }\end{array}$ & -2.97 & $\begin{array}{l}\text { VAL851, } \\
\text { SER854 }\end{array}$ & -3.23 & $\begin{array}{l}\text { LYS419, } \\
\text { LYS289 }\end{array}$ & -4.23 & $\begin{array}{l}\text { VAL2240, } \\
\text { TRP2239, } \\
\text { CYS2243 }\end{array}$ \\
\hline 6 & 2-Formylhistamine & -5.51 & $\begin{array}{l}\text { ASP933, } \\
\text { ASP810, } \\
\text { TYR836 }\end{array}$ & -6.43 & $\begin{array}{l}\text { ASP439, } \\
\text { GLU234 }\end{array}$ & -6.17 & $\begin{array}{l}\text { ASP2195, } \\
\text { ASP2357 }\end{array}$ \\
\hline 7 & 3-Bromo-2-pentanol & -4.19 & VAL851 & -3.48 & GLY294 & -4.29 & $\begin{array}{l}\text { GLY2238, } \\
\text { VAL2240 }\end{array}$ \\
\hline 8 & 5-Methoxy-3-Oxovalerate & -3.94 & $\begin{array}{l}\text { VAL851, } \\
\text { ASP933 }\end{array}$ & -3.9 & $\begin{array}{l}\text { GLY294, } \\
\text { LEU295, } \\
\text { LYS179 }\end{array}$ & -4.01 & VAL2240 \\
\hline 9 & Trans-2-Chlorovinylacetate & -4.16 & VAL851 & -4.52 & THR312 & -4.26 & VAL2240 \\
\hline 10 & Sec-butyl isopropyl ether & -4.24 & VAL851 & -4.52 & - & -4.64 & VAL2240 \\
\hline 11 & $\begin{array}{l}\text { Endo-2,3-O-Ethylidene-. } \\
\text { Beta.-D- Erythrofuranose }\end{array}$ & -3.45 & $\begin{array}{l}\text { VAL850, } \\
\text { GLU798, } \\
\text { ARG852 }\end{array}$ & -4.1 & $\begin{array}{l}\text { GLY294, } \\
\text { LEU295, } \\
\text { LYS179 }\end{array}$ & -3.82 & VAL2240 \\
\hline 12 & 1,7-Octanediol & -4.27 & $\begin{array}{l}\text { VAL851, } \\
\text { SER854, } \\
\text { GLU849 }\end{array}$ & -4.07 & $\begin{array}{l}\text { ALA230, } \\
\text { LEU156, } \\
\text { ASP439 }\end{array}$ & -4.16 & $\begin{array}{l}\text { ASP2195, } \\
\text { ASP2357, } \\
\text { VAL2240 }\end{array}$ \\
\hline 13 & $\begin{array}{l}\text { 3-Pentanone, } \\
\text { 1,5-Dimethoxy- Butane }\end{array}$ & -3.7 & VAL851 & -3.92 & GLY294 & -4.0 & VAL2240 \\
\hline 14 & 1,2-Propanediol diformate & -3.42 & $\begin{array}{l}\text { VAL851, } \\
\text { ASP933 }\end{array}$ & -4.3 & $\begin{array}{l}\text { LEU275, } \\
\text { ALA317, } \\
\text { TYR315 }\end{array}$ & -3.56 & VAL2240 \\
\hline 15 & $\begin{array}{l}\text { L-2-Amino-4-Methyl-1- } \\
\text { Pentanol }\end{array}$ & -4.78 & $\begin{array}{l}\text { ASP933, } \\
\text { ASP810 }\end{array}$ & -4.94 & GLU234 & -4.33 & - \\
\hline 16 & Propionic Acid & -3.04 & LYS924 & -2.52 & HIS207 & -2.99 & LYS2171 \\
\hline 17 & Acetal & -3.61 & VAL851 & -3.75 & $\begin{array}{l}\text { GLY294, } \\
\text { LEU295 }\end{array}$ & -3.94 & VAL2240 \\
\hline 18 & $\begin{array}{c}\text { 5-Methylene-2,4,7,9- } \\
\text { Tetraoxadecane }\end{array}$ & -3.09 & VAL851 & -3.08 & LEU295 & -3.64 & VAL2240 \\
\hline 19 & $\begin{array}{c}\text { (3-Methyl-Oxiran-2-YI)- } \\
\text { Methanol }\end{array}$ & -3.55 & $\begin{array}{l}\text { LYS802, } \\
\text { TYR836, } \\
\text { ASP933 }\end{array}$ & -4.01 & $\begin{array}{l}\text { ASP331, } \\
\text { ARG273, } \\
\text { LEU275 }\end{array}$ & -3.49 & VAL2240 \\
\hline 20 & $\begin{array}{l}\text { 4-Hydro-L-2-Amino-3- } \\
\text { Methyl-1- Pentanol }\end{array}$ & -2.5 & $\begin{array}{l}\text { SER854, } \\
\text { ASN853 }\end{array}$ & -2.79 & $\begin{array}{l}\text { LYS179, } \\
\text { GLY294, } \\
\text { ASN279, } \\
\text { ASP274 }\end{array}$ & -3.42 & CYS2243 \\
\hline 21 & Methyl Propyl Ether & -3.21 & VAL851 & -3.2 & LEU295 & -3.42 & VAL2240 \\
\hline 22 & Diglycolic Acid & -2.87 & $\begin{array}{l}\text { ARG770, } \\
\text { SER774 }\end{array}$ & -3.75 & $\begin{array}{l}\text { ARG206, } \\
\text { LYS214 }\end{array}$ & -3.44 & $\begin{array}{l}\text { TRP2239, } \\
\text { ARG2348, } \\
\text { LYS2171 }\end{array}$ \\
\hline
\end{tabular}




\begin{tabular}{|c|c|c|c|c|c|c|c|}
\hline 23 & 2-(2-Aminoethyoxy)-Ethanol & -4.11 & $\begin{array}{c}\text { ASP933, } \\
\text { LYS802, } \\
\text { ASP810 }\end{array}$ & -4.57 & $\begin{array}{c}\text { ASP439, } \\
\text { GLU234 }\end{array}$ & $\begin{array}{c}-4.35 \\
\text { ASP2357, } \\
\text { ASP2195 }\end{array}$ \\
\hline 24 & Chloromethoxy methane & -2.58 & VAL851 & -2.89 & LEU295 & -2.71 & VAL2240 \\
\hline 25 & $\begin{array}{c}\text { PI3K inhibitor (Alpelisib } \\
\text { (BYL719)) }\end{array}$ & -10.8 & $\begin{array}{c}\text { VAL851, } \\
\text { GLN859, }\end{array}$ & - & - & - \\
\hline 26 & $\begin{array}{c}\text { AKT inhibitor ((3R)-1-(5- } \\
\text { methyl-7H-pyrrolo[2,3-d] } \\
\text { pyrimidin-4-yl)pyrrolidin-3- } \\
\text { amine) }\end{array}$ & - & - & -8.49 & $\begin{array}{c}\text { GLU228, } \\
\text { ALA230 }\end{array}$ & - & - \\
\hline 27 & mTOR inhibitor (Torin 2) & - & - & - & - & -9.82 & VAL2240, \\
THR2245
\end{tabular}

and partially orange that indicates cells undergoing apoptosis and late apoptosis.

Mitochondrial membrane potential (MMP) changes in cells with and without LOJ treatment were stained with Rhodamine 123, and the results showed the accumulation of dye in untreated cells, which shows good mitochondrial membrane potential. A significant reduction in dye accumulation in treated cells was observed that shows the loss of MMP (Figure 4a, 4b).

ROS levels were measured by flow cytometry analysis (Figure 4c, 4d). The cellular esterases convert nonpolar DCFH-DA into polar DCFH. A nonfluorescent DCFH oxidized to fluorescent DCF by intracellular ROS. Thus, the increase in ROS levels shows high fluorescence. Control cells showed a $0.10 \%$ ROS level, whereas LOJ treated cells showed $56.51 \%$ ROS levels. As shown in the results, we observed high ROS levels in LOJ treated cells. Mitochondria-mediated apoptosis was further confirmed by quantification of caspase 9 levels in LOJ treated cells. The mitochondria-mediated apoptosis pathway involved in the loss of MMP and cytochrome C release that activates pro-caspase 9 cleavage. $^{21}$ As indicated (Figure 4e), increased caspase 9 levels were detected in LOJ treated cells than in the untreated control cells.

To further support LOJ induced apoptosis, the mRNA levels of PI3K/AKT/mTOR were quantified by qRTPCR. The PI3K/AKT/mTOR pathway is correlated with apoptosis, cell growth and proliferation. Thus, inhibition of this pathway could drive cancer cell apoptosis and prevent proliferation as well. We observed down-regulation of mRNA levels of PI3K (fold change - 8.26) and AKT (fold change - 5.54) but moderate up-regulation (fold change - 1.40) of mTOR in LOJ treated MCF-7 cells related to the control cells (Figure 5), confirming cancer cell apoptosis via down-regulation of $\mathrm{PI} 3 \mathrm{~K} \alpha$ and $\mathrm{AKT}$ genes.

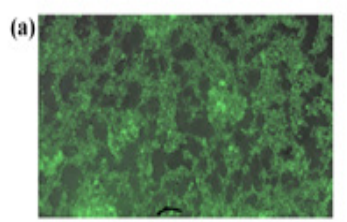

(c)

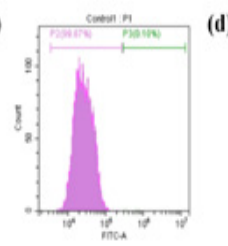

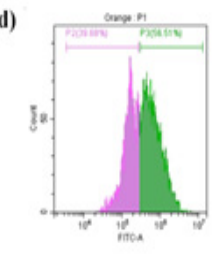

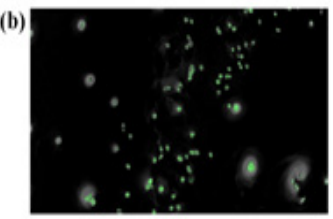

(e)

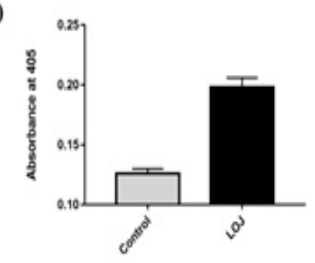

Figure 4: Rhodamine 123 staining for mitochondrial membrane potential to find the apoptosis in mitochondria (100X magnification): (a) Control cells, (b) LOJ treated cells; Measurement of ROS levels by flow cytometry: (c) Control cells, (d) LOJ treated cells; (e) caspase 9 activity of control and LOJ treated cells.

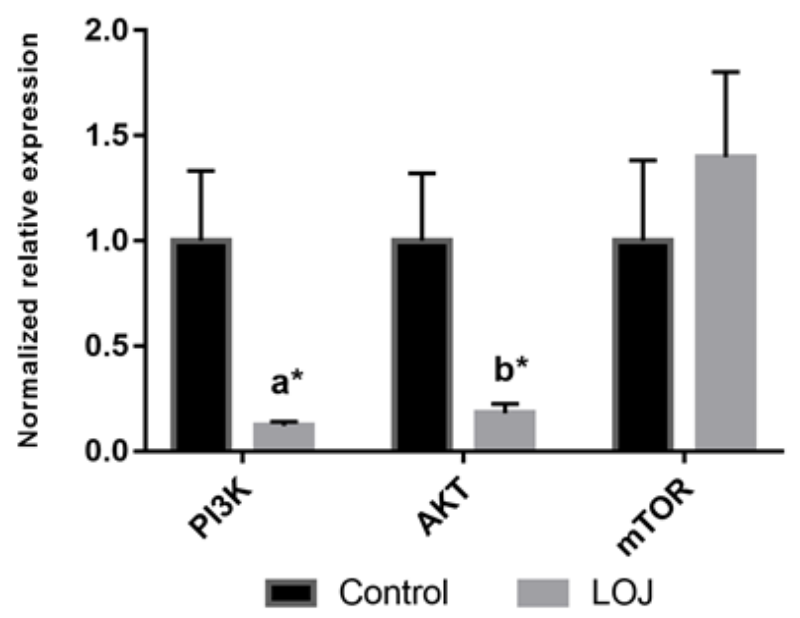

Figure 5: mRNA expression levels of PI3K/AKT/mTOR were quantified by RT-PCR using $\beta$ - Actin as a reference gene. The reduction in PI3K and AKT expressions were observed in cells treated with LOJ. * $=p<0.05 ; a=$ Comparison of PI3K control with PI3K in LOJ treatment, $b=$ Comparison of AKT control with AKT in LOJ treatment. 


\section{DISCUSSION}

Appropriate food, balanced nutrition and regular exercise can prevent cancer by at least 30 to $40 \%{ }^{22}$ Most of the food components are biologically active and prevent cancer that is yet to be elucidated scientifically. These components are fatty acids, phytochemicals (flavonoids, isothiocyanates and retinoids) and selenium. ${ }^{23}$ It is proven that diet is an epigenetic modulator that changes the gene expression pattern. ${ }^{24}$ Flavonoids have an important role in epigenetic remodelling and improve human health. ${ }^{25}$ Flavonoids also target other major pharmacological pathways, such as anti-angiogenesis, anti-apoptotic and anti-inflammatory. ${ }^{26,27}$ Though the in vitro and in vivo studies on flavonoids are still limited and yet to be elucidated. ${ }^{28}$ In this study, the chemopreventive effect of lyophilised orange juice powder and its mechanism through which it acts has been reported. Phenolic compounds are a diverse class of phytocompounds that show chemotherapeutic and chemopreventive effects. The redox properties of phenolic compounds function as antioxidants in the prevention of cancer. ${ }^{29}$ Flavonoids, also called Vitamin P, the plant secondary metabolites giving characteristic colours to plants, also play a pivotal role in anti-inflammatory, anticancer and antioxidant activities. $^{30}$ Earlier reports have already shown the concentration-dependent polyphenols and flavonoids activity in cancer prevention. ${ }^{31}$ Radical scavenging activity is essential to protect the biological system from free radicals. The experimental data indicated radical scavenging of LOJ showed high antioxidant activity. The correlation between TPC and TFC with antioxidant activity showed a positive correlation.

In most human cancers, the PI3K/AKT/mTOR pathway holds a significant role in cancer progression and proliferation. ${ }^{32}$ This pathway is also correlated with apoptosis and cell growth. The PI3K/AKT/mTOR inhibition could lead to apoptosis of cancer cells and also prevent proliferation. ${ }^{33}$ Hence, this pathway is considered as one of the major therapeutic targets in anticancer drug discovery. The PI3K subunit is mutated in $18-40 \%$ of breast cancers. ${ }^{34}$ Thus, it is an ideal target for drug development. Inhibition of the breast cancer cell line could be attributed to the ameliorative effects of phytocompounds present in the orange juice, such as phenols, flavonoids, alcohols and acids. A previous study showed that breast cancer cells' inhibition by polymethoxyflavones (PMFs) from $C$. sinensis and a clinical study involving postmenopausal breast cancer patients showed that a high amount of flavones in orange juice might reduce mortality. ${ }^{35,36}$ Decreased mitochondrial membrane potential, and increased ROS levels are linked to apoptosis. The loss of MMP activates cleavage of caspase 9. The mitochondrial membrane is an essential parameter for assessing mitochondrial function. ${ }^{37}$ Our results depicted that MCF-7 cells with LOJ treatment had reduced mitochondrial membrane potential, increased ROS levels and increased caspase 9 activities compared to control cells. Also, suppression of the PI3K/AKT pathway is associated with mitochondria-mediated apoptosis. ${ }^{38}$ In line with that, qRT-PCR results showed down-regulation of the PI3K and AKT genes responsible for ROS induced caspase 9-mediated apoptosis.

\section{CONCLUSION}

Lyophilised orange juice (LOJ) showed promising antioxidant and cytotoxic activity against breast cancer cell lines via mitochondria-mediated apoptosis and down-regulation of PI3K and AKT genes. The moderate non-significant up-regulation of mTOR was observed. Moreover, the overall interaction of LOJ compounds with the $\mathrm{PI} 3 \mathrm{~K} / \mathrm{AKT} / \mathrm{mTOR}$ protein targets was predictably high. This concludes that LOJ possibly acts via PI3K/AKT inhibition, leading to mitochondria-mediated apoptosis and anti-proliferation in breast cancer cells.

\section{ACKNOWLEDGEMENT}

The authors acknowledge VIT management for providing necessary facilities and financial support to carry out this work.

\section{CONFLICT OF INTEREST}

The authors declare that there are no conflicts of interest.

\section{ABBREVIATIONS}

LOJ: Lyophilized orange juice; ROS: Reactive oxygen species; PI3K: Phosphatidylinositol-3-kinase; AKT: Protein kinase B; mTOR: Mammalian target of rapamycin; DPPH: 2,2-diphenyl-1-picrylhydrazyl; DMEM: Dulbecco's Modified Eagle's Medium; MTT: (3-(4,5-dimethylthiazol-2-yl) 2,5-diphenyltetrazolium bromide); AO/EB: Acridine orange/ Ethidium bromide.

\section{REFERENCES}

1. Jemal A, Bray F, Center MM, Ferlay J, Ward E, Forman D. Global cancer statistics. CA: A Cancer Journal for Clinicians. 2011;61(2):69-90.

2. Cazzaniga M, Bonanni B. Breast cancer chemoprevention: Old and new approaches. Bio Med Research International. 2012;2012. 
3. Kannan K, Jain SK. Oxidative stress and apoptosis. Pathophysiology. 2000;7(3):153-63.

4. Li P, Zhou L, Zhao T, Liu X, Zhang P, Liu Y, et al. Caspase-9: Structure, mechanisms and clinical application. Oncotarget. 2017;8(14):23996.

5. Aruoma OI. Free radicals, oxidative stress and antioxidants in human health and disease. Journal of the American oil chemists' society. 1998;75(2):199212.

6. Liang Q, Xiao Y, Liu K, Zhong C, Zeng M, Xiao F. Cr (VI)-induced autophagy protects L-02 hepatocytes from apoptosis through the ROS-AKT-mTOR pathway. Cellular Physiology and Biochemistry. 2018;51(4):1863-78.

7. Zhang J, Wang X, Vikash V, Ye Q, Wu D, Liu Y, et al. ROS and ROS-mediated cellular signaling. Oxidative Medicine and Cellular Longevity. 2016.

8. Li D, Ni S, Miao KS, Zhuang C. PI3K/Akt and caspase pathways mediate oxidative stress-induced chondrocyte apoptosis. Cell Stress and Chaperones. 2019;24(1):195-202.

9. Koohpar ZK, Entezari M, Movafagh A, Hashemi M. Anticancer activity of curcumin on human breast adenocarcinoma: role of Mcl-1 gene. Iranian Journal of Cancer Prevention. 2015;8(3).

10. Okwu D, Emenike I. Evaluation of the phytonutrients and vitamin contents of citrus fruits. Int J Mol Med Adv Sci. 2006;2(1):1-6.

11. Zhao J. Nutraceuticals, nutritional therapy, phytonutrients, and phytotherapy for improvement of human health: A perspective on plant biotechnology application. Recent Patents on Biotechnology. 2007;1(1):75-97.

12. Yang M, Coles BF, Caporaso NE, Choi Y, Lang NP, Kadlubar FF. Lack of association between Caucasian lung cancer risk and O6-methylguanineDNA methyltransferase-codon 178 genetic polymorphism. Lung Cancer. 2004;44(3):281-6.

13. Okwu D. Phytochemicals, vitamins and mineral contents of two Nigerian medicinal plants. Int J Mol Med Adv Sci. 2005;1(4):375-81.

14. Kaur C, Kapoor HC. Antioxidant activity and total phenolic content of some Asian vegetables. International Journal of Food Science and Technology. 2002;37(2):153-61.

15. Chen HW, Chou FP, Lue SI, Hsu HK, Yang RC. Evidence of multistep regulation of HSP72 expression in experimental sepsis. Shock. 1999;12(1):63-8.

16. Mensor LL, Menezes FS, Leitão GG, Reis AS, Santos TCD, Coube CS, et al. Screening of Brazilian plant extracts for antioxidant activity by the use of DPPH free radical method. Phytotherapy Research. 2001;15(2):127-30.

17. Berman HM. The protein data bank: A historical perspective. Acta Crystallographica Section A: Foundations of Crystallography. 2008;64(1):8895.

18. Ramalingam V, Revathidevi S, Shanmuganayagam T, Muthulakshmi L, Rajaram R. Biogenic gold nanoparticles induce cell cycle arrest through oxidative stress and sensitize mitochondrial membranes in A549 lung cancer cells. RSC Advances. 2016;6(25):20598-608.

19. Diplock AT. Will the 'good fairies' please prove to us that vitamin $E$ lessens human degenerative disease?. Free Radical Research. 1997;27(5):511-32.

20. Pires DE, Blundell TL, Ascher DB. pkCSM: Predicting small-molecule pharmacokinetic and toxicity properties using graph-based signatures. Journal of Medicinal Chemistry. 2015;58(9):4066-72.

21. Hu H, Jiang C, Li G, Lü J. PKB/AKT and ERK regulation of caspasemediated apoptosis by methylseleninic acid in LNCaP prostate cancer cells. Carcinogenesis. 2005;26(8):1374-81.
22. Ong TP, Moreno FS, Ross SA. Targeting the epigenome with bioactive food components for cancer prevention. Lifestyle Genomics. 2011;4(5):275-92.

23. Berghe WV. Epigenetic impact of dietary polyphenols in cancer chemoprevention: lifelong remodeling of our epigenomes. Pharmacological Research. 2012;65(6):565-76.

24. Hardy TM, Tollefsbol TO. Epigenetic diet: Impact on the epigenome and cancer. Epigenomics. 2011;3(4):503-18.

25. Lee WJ, Shim JY, Zhu BT. Mechanisms for the inhibition of DNA methyltransferases by tea catechins and bioflavonoids. Molecular Pharmacology. 2005;68(4):1018-30.

26. Harbone J, Williams C. Review: Advances in flavonoid research since. Phytochem. 2000.

27. Kanadaswami C, Lee LT, Lee PPH, Hwang JJ, Ke FC, Huang YT, et al. The antitumor activities of flavonoids. In vivo. 2005;19(5):895-909.

28. Gerhauser C. Cancer chemoprevention and nutri-epigenetics: State of the art and future challenges. Natural Products in Cancer Prevention and Therapy: Springer. 2012;73-132.

29. Soobrattee MA, Neergheen VS, Luximon-Ramma A, Aruoma OI, Bahorun T. Phenolics as potential antioxidant therapeutic agents: Mechanism and actions. Mutation Research/Fundamental and Molecular mechanisms of mutagenesis. 2005;579(1-2):200-13.

30. Crozier A, Yokota T, Jaganath IB, Marks SC, Saltmarsh M, Clifford MN. Secondary metabolites in fruits, vegetables, beverages and other plant based dietary components. Plant Secondary Metabolites: Occurrence, Structure and Role in the Human Diet. 2006;208-302.

31. Campbell MK, Carr C, DeVellis B, Switzer B, Biddle A, Amamoo MA, et al. $A$ randomized trial of tailoring and motivational interviewing to promote fruit and vegetable consumption for cancer prevention and control. Annals of Behavioral Medicine. 2009;38(2):71-85.

32. Ghayad SE, Cohen PA. Inhibitors of the PI3K/Akt/mTOR pathway: New hope for breast cancer patients. Recent Patents on Anticancer Drug Discovery. 2010;5(1):29-57.

33. Kim KY, Park KI, Kim SH, Yu SN, Park SG, Kim YW, et al. Inhibition of autophagy promotes salinomycin-induced apoptosis via reactive oxygen species-mediated PI3K/AKT/mTOR and ERK/p38 MAPK-dependent signaling in human prostate cancer cells. International Journal of Molecular Sciences. 2017;18(5):1088.

34. Liu P, Cheng H, Roberts TM, Zhao JJ. Targeting the phosphoinositide 3-kinase pathway in cancer. Nature Reviews Drug Discovery. 2009;8(8):627-44.

35. Sergeev IN, Ho CT, Li S, Colby J, Dushenkov S. Apoptosis-inducing activity of hydroxylated polymethoxyflavones and polymethoxyflavones from orange peel in human breast cancer cells. Molecular Nutrition and Food Research. 2007;51(12):1478-84.

36. Fink BN, Steck SE, Wolff MS, Britton JA, Kabat GC, Gaudet MM, et al. Dietary flavonoid intake and breast cancer survival among women on Long Island. Cancer Epidemiology and Prevention Biomarkers. 2007;16(11):2285-92.

37. Miwa S, Jow H, Baty K, Johnson A, Czapiewski R, Saretzki G, et al. Low abundance of the matrix arm of complex I in mitochondria predicts longevity in mice. Nature Communications. 2014;5(1):1-12.

38. Huang Y, Hu J, Zheng J, Li J, Wei T, Zheng Z, et al. Down-regulation of the PI3K/Akt signaling pathway and induction of apoptosis in CA46 Burkitt lymphoma cells by baicalin. Journal of Experimental and Clinical Cancer Research. 2012;31(1):48.

\section{SUMMARY}

Citrus fruits are a source of flavanones, flavones and polymethoxylated flavones that has myriad bioactivities. Our data showed that lyophilized orange juice (LOJ) is rich in phenolic acids and flavonoids, thus scavenging reactive oxygen species. LOJ acts via PI3K/AKT inhibition, leading to mitochondria-mediated apoptosis and antiproliferation in breast cancer cell line (MCF-7). 
PICTORIAL ABSTRACT

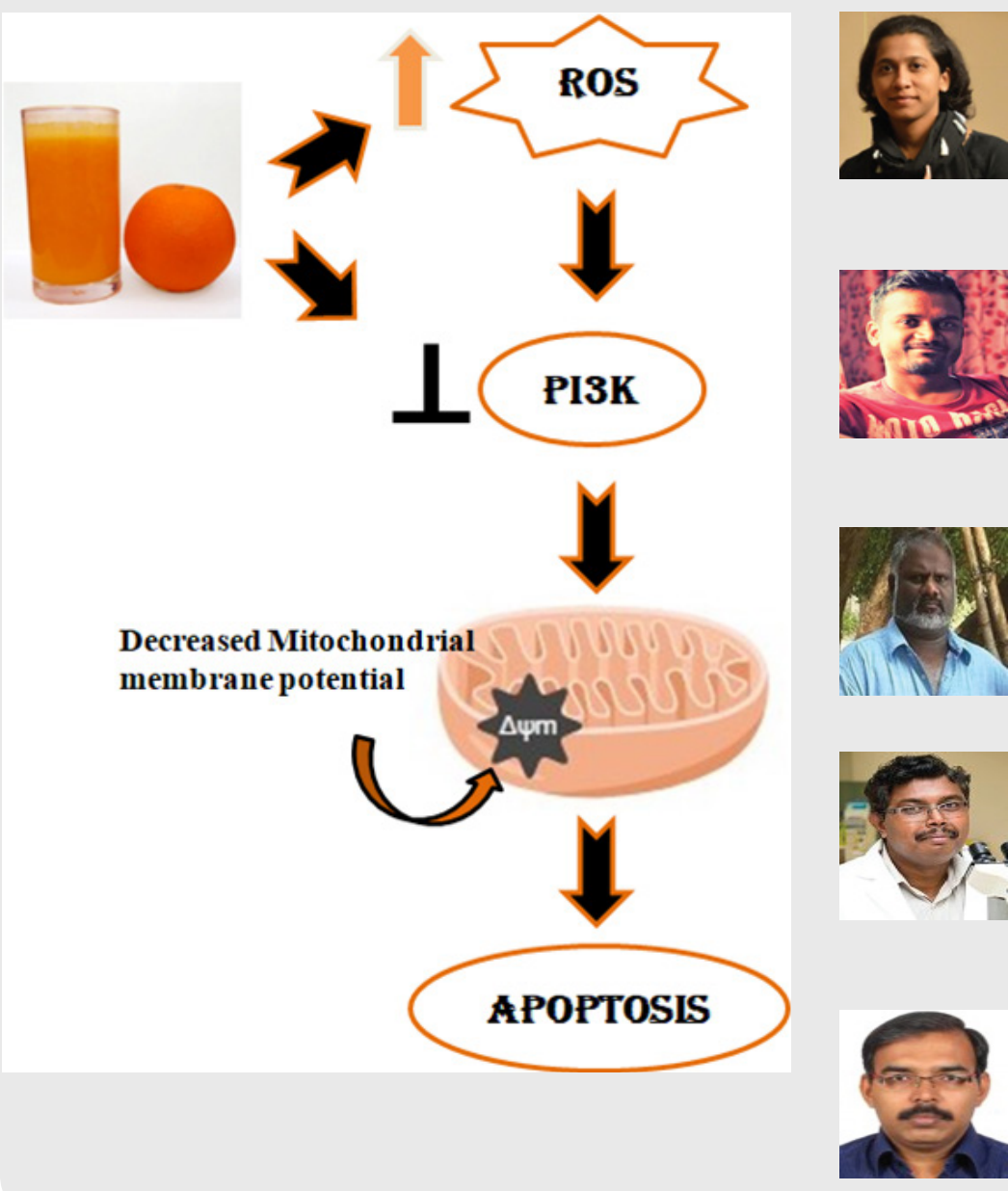

\section{About Authors}

Dr. Jayasindu Mathiyazhagan pursued Ph.D in School of Bio Sciences and Technology, Vellore Institute of Technology (VIT), working on phytotheraphy and diseases. She is interested in metabolism, epigenetics, phytomedicines and molecular biology

Mr. Arul Daniel is currently pursuing Ph.D in School of Bio Sciences and Technology, Vellore Institute of Technology (VIT), working in the field of biomedicine and therapy. He is skilled in nanomedicine, animal studies and molecular biology.

Dr. George Priya Doss is an Assistant Professor at Vellore Institute of Technology (VIT), India. His research interests include Bioinformatics, Biosciences and Technology and Nanobiotechnology.

Dr. Rama Jayaraj is a veterinarian and applied biotechnologist. He is working as a Theme Lead - Advanced Studies at Flinders University, Australia. He is skilled in Research Design, Metaanalysis, Science, Statistics, and Research.

Dr. K.M. Gothandam is a Professor at Vellore Institute of Technology (VIT), India. His research interests include Plant molecular biology, Functional genomics and phytotherapy.

Cite this article: Mathiyazhagan J, Daniel JA, Doss CGP, Jayaraj R, Gothandam KM. Lyophilized Fruit Juice of Citrus sinensis Triggers Mitochondria-mediated Apoptosis via Down-regulation of PI3K/AKT in MCF-7 Cell Line. Indian J of Pharmaceutical Education and Research. 2021;55(2):556-65. 